\title{
Pengenalan BISMETIK++ Bagi Keluarga Petani Nelayan di Gampong Langung Kabupaten Aceh Barat
}

\author{
Introduction of BISMETIK++ for Small Farmer in Langung Village \\ Kabupaten Aceh Barat
}

\author{
Farah Diana ${ }^{1}$,Afrizal Hendri ${ }^{1}$, Sufal Diansyah ${ }^{1}$, Kairul Samuki ${ }^{2}$, Wahyu Anas ${ }^{2}$, Rahmad Wahyudi², Muhajir \\ Ansar², Ariadi Ben², Irwansyah², Shela Rahmita² $^{2}$ \\ ${ }^{1}$ Program Studi Akuakultur, Fakultas Perikanan dan Ilmu Kelautan, Universitas Teuku Umar, Meulaboh, \\ Aceh, Indonesia. ${ }^{2}$ Program Studi Perikanan, Fakultas Perikanan dan Ilmu Kelautan, \\ Universitas Teuku Umar, Meulaboh, Aceh, Indonesia \\ *Korespondensi : hendri2020@gmail.com
}

\begin{abstract}
ABSTRAK
Hasil focus group discussion (FGD) dengan beberapa orang nelayan/pembudidaya didapatkan beberapa permasalahan diantaranya harga benih ikan yang cukup mahal di wilayah Aceh Barat, harga pakan (pellet) ikan yang cukup mahal, ikan sering lepas dari wadah kurungan karena air pasang atau jaring sobek, proses pembudidayaan dilakukan secara tradisional,harga ikan konsumsi yang tidak mengalami kenaikan jika dibandingkan dengan harga pakan yang terus mengalami kenaikan serta manajemen usaha yang belum rapih. Adapun tujuan dari kegiatan ini yaitu mitra mendapatkan IPTEKS tentang budidaya ikan (produksi pakan mandiri, pembesaran ikan dengan aplikasi bioflok di wadah bismetik, produksi sayur organik dari limbah budidaya, dan pengolahan hasil panen bagi ibu-ibu rumah tangga nelayan). Pendekatan yang digunakan terhadap persoalaan mitra adalah metode ceramah dan praktikum. Sedangkan cara atau tahapan untuk keberhasilan program meliputi identifikasi masalah, analisis kebutuhan, penyusunan program, pelaksanaan program, monitoring dan evaluasi berdasarkan indikator keberhasilan program, lokakarya hasil dengan menghadirkan stakeholder program dan pelaporan. Adapun kegiatan yang telah dilakukan yaitu pembesaran ikan dimana pembesaran ikan ini merupakan salah satu segmen usaha yang banyak dilakukan para pembudidaya ikan. selanjutnya adalah kegiatan pembuatan pakan ikan, kegiatan yang telah dilakukan yaitu pemesanan mesin pakan dan penyuluhan pembuatan pakan kepada masyarakat desa Langung,dan seterusnya kegiatan akuaponik yaitu kegiatan mengelola limbah sisa metabolisme ikan dengan pemanfaatan tanaman pada kolam akuaponik.
\end{abstract}

Kata Kunci : Bismetik ++, Lele sangkuriang, Aquaponik, Langung

\begin{abstract}
FGD results with some fishermen/farmers obtained several problems including the fish seed price is quite expensive in Aceh Barat regency, the price of feed (pellets) quite expensive fish, the fish often escape from confinement containers because the tide or rip nets, the process of cultivation is done traditionally, fish consumption rates did not increase when compared to the price of feed has continued to increase as well as the management of the business which has not been neat. As for the purpose of this activity, namely the partners get IPTEKS about cultivation of fish (the production of fish feed is independent, the enlargement with the application bioflok in bismetik container, organic vegetable production from aquaculture wastes, processing crops for mother-housewife fishermen). The approach that was used against the subject's partner is a method of lecture and lab course. While the way or stages for the success of the programs include problem identification, needs analysis, preparation of programs, program implementation, monitoring and evaluation based on the indicators of success of the program, the workshop results by presenting program stakeholders and reporting. As for the activities that have been carried out, namely the enlargement the enlargement of this fish where
\end{abstract}


fish is one of the many business segments performed the fish farmers. Next up is the making of fish feed activities, activities that have been undertaken, namely booking engine feed feed creation and outreach to the community of the village directly, and so on aquaponik activities, namely activities manage wastes the rest of metabolism the fish with the utilization of plants in outdoor aquaponik.

Key words : Bismetik ++, Channel Catfish, Aquaponik, Langung

\section{PENDAHULUAN}

Gampong Langung adalah salah gampong pesisir yang terletak diKecamatan Meureubo Kabupaten Aceh Barat. Gampong ini memiliki luas 2.27KM2 yang terdiri atas 4 dusun denganjumlah penduduk 2.033 jiwa atau terdapat465 rumah tangga (BPS Kab. Aceh Barat, 2014).

Gampong ini merupakan salah satu gampong yang memiliki tingkat produksi ikan air tawar cukup besar di wilayah Meureubo, dengan rata-rata 45 ton per tahun dari kegiatan budidaya dan 40 ton dari kegiatan penangkapan di perairan umum. Kegiatan budidaya yang telah dikembangkan adalah metode jaring tancap di tepi sungai (BPS Kab. Aceh Barat, 2014). Terdapat 25 rumah tangga yang melakukan usaha budidaya ikan.

Hasil FGD dengan beberapa orang nelayan/pembudidaya didapatkan beberapa permasalahan diantaranya harga benih ikan yang cukup mahal di wilayah Aceh Barat, harga pakan (pellet) ikan yang cukup mahal, ikan sering lepas dari wadah kurungan karena air pasang atau jaring sobek, proses pembudidayaan dilakukan secara tradisional,harga ikan konsumsi yang tidak mengalami kenaikan jika dibandingkan dengan harga pakan yang terus mengalami kenaikan serta manajemen usaha yang belum rapi

Oleh karena itu, program pengabdian ini bertujuan agar mitra mendapatkan IPTEKS tentang budidaya ikan (produksi pakan mandiri, pembesaran ikan dengan aplikasi bioflok di wadah bismetik, produksi sayur organik dari limbah budidaya, pengolahan hasil panen bagi ibu-ibu rumah tangga nelayan) dan meningkatnya Income per kapita mitra serta menjadi desa binaan.

\section{METODOLOGI}

Pendekatan yang digunakan terhadap persoalaan mitra adalah metode ceramah dan praktikum. Sedangkan cara atau tahapan untuk keberhasilan program (Lampiran 1).

\section{Identifikasi Masalah}

Gampong Langung merupakan salah satu gampong yang cukup banyak terdapat pembudidaya ikan. Umumnya masih bersifat tradisional, dengan wadah kultur berupa pen-culture (berupa kandang) dan keramba jaring tancap. Penggunaan wadah ini memiliki beberapa kelemahan diantaranya ikan seringlepas dari wadah kurungan karena air pasang yang tinggi, jaring sobek, tumpahan minyak/oli kapal nelayan lengket ke jaring. Selain itu pembudidaya mengeluhkan harga benih ikan, pakan ikan (pellet) yang cukup mahal di wilayah Aceh Barat, harga ikan konsumsi yang tidak mengalami kenaikan jika dibandingkan dengan harga pakan yang terus mengalami kenaikanserta manajemen usaha yang belum rapi. Akibatnya sepintas terlihat aktivitas 
pembesaran ikan di gampong ini belum menjadi profesi utama karena secara signifikanbelum memberikan nilai lebih bagi ekonomi keluarga mereka.

\section{Analisis Kebutuhan}

Hasil FGD di Gampong Langong terlihat bahwa mitra sangat membutuhkan solusi yang tepat untuk mengatasi persoalaan dan keberlangsungan aktivitas pembesaran ikan (budidaya ikan air tawar). Berikut ini kebutuhan yang diperlukan mitra terkait dengan kegiatan pembesaran ikan, diantaranya (1) metode lain untuk wadah kultur ikan yang mudah dalam pengontrolan/efisien/ramah lingkungan, (2) alternatif pakan buatan yang murah, tetapi memberikan nilai pertumbuhan yang baik bagi ikan, (3) untuk mendapatkan nilai tambah dari kegiatan pembesaran ikan, maka perlu dilakukan pemanfaatan media kultur (limbah) untuk menanam sayur (akuaponik), (4) diversifikasi produk pembesaran untum meningkatkan nilai jual ikan hasil pembesaran seperti diolah menjadi ikan salai/asap.

\section{Penyusunan Program}

Program pengabdian ini disusun berdasarkan temuan-temuan yang didapat dilapangan/mitra, diantaranya (1) sosialisasi program ke wilayah mitra, (2) pelatihan pembuatan kolam bis metik, (3) pelatihan pembuatan pakan (pellet), (4) pelatihan budidaya sayur organik (akuaponik) bagi ibu-ibu nelayan/petani, (5)pelatihan pengolahan ikan hasil budidaya bagi ibu-ibu nelayan/petani, (6) pelatihan manajemen usaha sederhana/keuangan, (7) pendampingan dan monev.

\section{Pelaksanaan Program}

Porgram ini telah dilaksanakan selama 6 bulan di Gampong Langung, dengan pendekatan ceramah dan praktikum (sesuai dengan gambaran ipteks yang akan diterapkan).

\section{Monitoring dan Evaluasi}

Untuk mencapai indikator keberhasilan program yang telah disusun, seperti (1) mitra mampu memproduksi benih ikan, pakan ikan secara mandiri, (2) terbentuknya unit produksi benih dan pakan di tempat mitra, (3) terjalinnya kemitraan dengan berbagai pihak (mitra-kampus-pemerintah desa-pelaku usaha), (4) terbentuknya kelembagaan lokal di masyarakat yang meneruskan dan mengembangkan program. Maka monitoring dilakukan setiap satu minggu.

Evaluasi dilakukandengan cara membandingkan indikator (perilaku, fisik,kelembagaan, tindak lanjut) sebelum dan sesudah pelaksanaan program bina desa. Data-data perubahan tersebut dapat diperoleh denganmetode wawancara/FGD dan observasi.

\section{Lokakarya Hasil}

Lokakarya dilakukan pada bulan kelima pada pelaksanaan program, dengan mengahadirkan mitra, pemerintah desa dan pihak kampus. Lokakarya ini akan membahas hal-hal penting yang ditemui di lapanganseperti kendala dalam pelaksanaan program,dampak keberhasilan program, keterlibatan mitra, 
keberlanjutanprogram berdasarkan kebutuhan mitra, peluang pasar dan feedback/saran dari peserta program.

\section{HASIL DAN PEMBAHASAN}

\section{Pembesaran Ikan}

Pembesaran ikan merupakan proses budidaya yang bertujuan untuk memperoleh ikan ukuran konsumsi. Budidaya pembesaran ikan merupakan salah satu segmen usaha yang banyak dilakukan para pembudidaya ikan. Pembesaran ikan relatif lebih mudah karena keterampilan yang dibutuhkan sangat sederhana dibandingkan melakukan pembenihan. Teknik yang perlu diperhatikan adalah memilih wadah budidaya, memilih benih, padat penebaran, pola pemberian pakan, pencegahan hama dan penyakit ikan, pengontrolan pertumbuhan (sampling, grading dan sortasi), pengelolaan kualitas air yang tepat serta, panen dan pascapanen.Padat tebar tiap kolam yaitu 2000, 2000 dan 1000 ekor.

Tabel 1. Produksi ikan lele dari kolam bismetik (kg), selama 3 bulan pemeliharaan

\begin{tabular}{ccc}
\hline Kolam 1 & Kolam 2 & Kolam 3 \\
\hline 217 & 203 & 75 \\
\hline
\end{tabular}

Dalam kegiatan program hibah bina desa, kegiatan pembesaran ikan merupakan kegiatan awal dari program ini, pembesaran ikan yang dilakukan dengan jenis komoditi ikan lele sangkuriang. Adapun serangkaian kegiatan pembesaran dimulai dari pembuatan wadah budidaya ikan dengan kontruksi menggunakan besi wiremesh sebagai penyanggah kolam budidaya serta terintegrasi dengan system aquaponik.

Pencapaian dari kegiatan pembesaran ikan di lapangan meliputi kegiatan persiapan lahan, persiapan alat dan bahan serta pembuatan wadah budidaya yang terintegrasi aquaponik.

\section{Pembuatan Pakan}

Pembuatan pakan ikan merupakan salah satu faktor terpenting dalam suatu usaha budidaya perikanan. Ketersediaan pakan akan berpengaruh terhadap pertumbuhan dan kelangsungan hidup ikan yang dibudidayakan. Dalam proses budidaya ikan khususnya pada kegiatan pembesaran, faktor terpenting adalah ketersediaan pakan dalam jumlah yang cukup. Pakan memberikan kontribusi terbesar yaitu mencapai $60-70 \%$ dari total biaya produksi dan pakan tersebut harus mengandung seluruh nutrien yang diperlukan seperti karbohidrat, lemak, protein, mineral dan vitamin serta asam amino esensial dalam jumlah cukup dan seimbang. Kondisi tersebut sangat dibutuhkan bagi usaha bidang budidaya perikanan termasuk pada budidayaikan lele sangkuriang pada program hibah bina desa yang sedang dijalankan ini.

Kegiatan pembuatan pakan ikan yang telah dilakukan adalah dengan mamanfaatkan bahan baku lokal. Pertimbangannya adalah ketersediaan dan harga yang terjangkau. Kegiatan ini bertjuan masyarakat dapat memanfaatkan bahan-bahan lokal yang berpotensi menjadi pemasukan bagi para pembudidaya ikan didesa ini. 
Jenis pakan yang diproduksi adalah pelet tenggelam, diameter $4 \mathrm{~mm}$ dan crude protein $18 \%$.

\section{Akuaponik}

Aquaponik adalah sistem perikanan berkelanjutan yang mengkombinasi kan akuakultur dan hidroponik dalam lingkungan yang bersifat simbiotik. Dalam akuakultur yang normal, ekskresi dari hewan yang dipelihara akan terakumulasi di air dan meningkatkan toksisitas air jika tidak dibuang.Pada kegiatan aquaponik ini limbah sisa metabolisme ikan dimasukan kedalam kolam aquaponik dan selanjutnya limbah ini akan dimanfaatkan oleh tanaman pada kolam aquaponik. Jenis tanaman yang dikulturkan adalah kangkung dan bayam. Tanaman kangkung sudah bisa dipanen pada usia pemeliharaan 30 hari dari media kultur air limbah pembesaran ikan lele.

\section{PENUTUP}

\section{Kesimpulan}

1. Pembesaran ikan merupakan proses budidaya yang bertujuan untuk memperoleh ikan ukuran konsumsi.

2. Kegiatan pembesaran ikan yang telah dilakukan meliputi kegiatan persiapan lahan, persiapan alat dan bahan serta pembuatan wadah budidaya yang terintegrasi aquaponik.

3. Pembuatan pakan ikan merupakan salah satu faktor terpenting dalam suatu usaha budidaya perikanan. Ketersediaan pakan akan berpengaruh terhadap pertumbuhan dan kelangsungan hidup ikan yang dibudidayakan.

4. Aquaponik adalah sistem perikanan berkelanjutan yang mengkombinasi kan akuakultur dan hidroponik dalam lingkungan yang bersifat simbiotik.

\section{UCAPAN TERIMA KASIH}

Terima kasih kepada Belmawa Dikti yang telah mendanai kegiatan ini, Geuchik beserta aparatrur Gampong Langong yang telah memfasilitasidan mendukung penuh kegiatan sampai selesai, selanjutnya kepada mitra kegiatan yang telah antusias dan berpartisipasi dalam kegiatan ini, serta kepada TIM PHBD BISMETIK ${ }^{++}$yang sudah bersusah payah membantu kegiatan ini sampai dengan selesai, serta FPIK UTU yang telah mensupport.

\section{Lampiran 1. Tahapan Kegiatan}

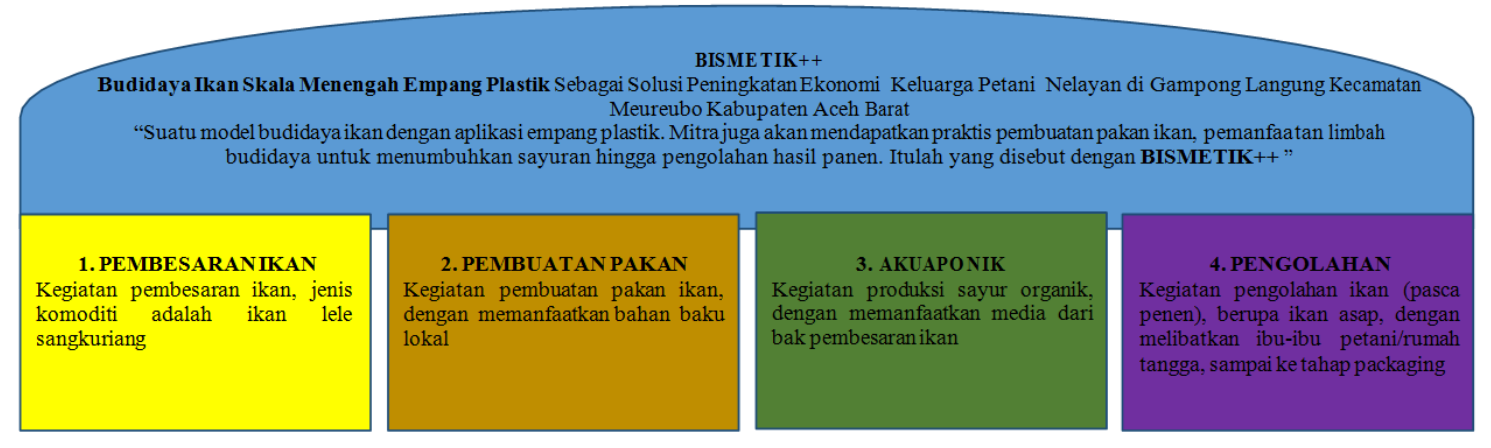




\section{Lampiran 2. Dokumentasi Kegiatan}
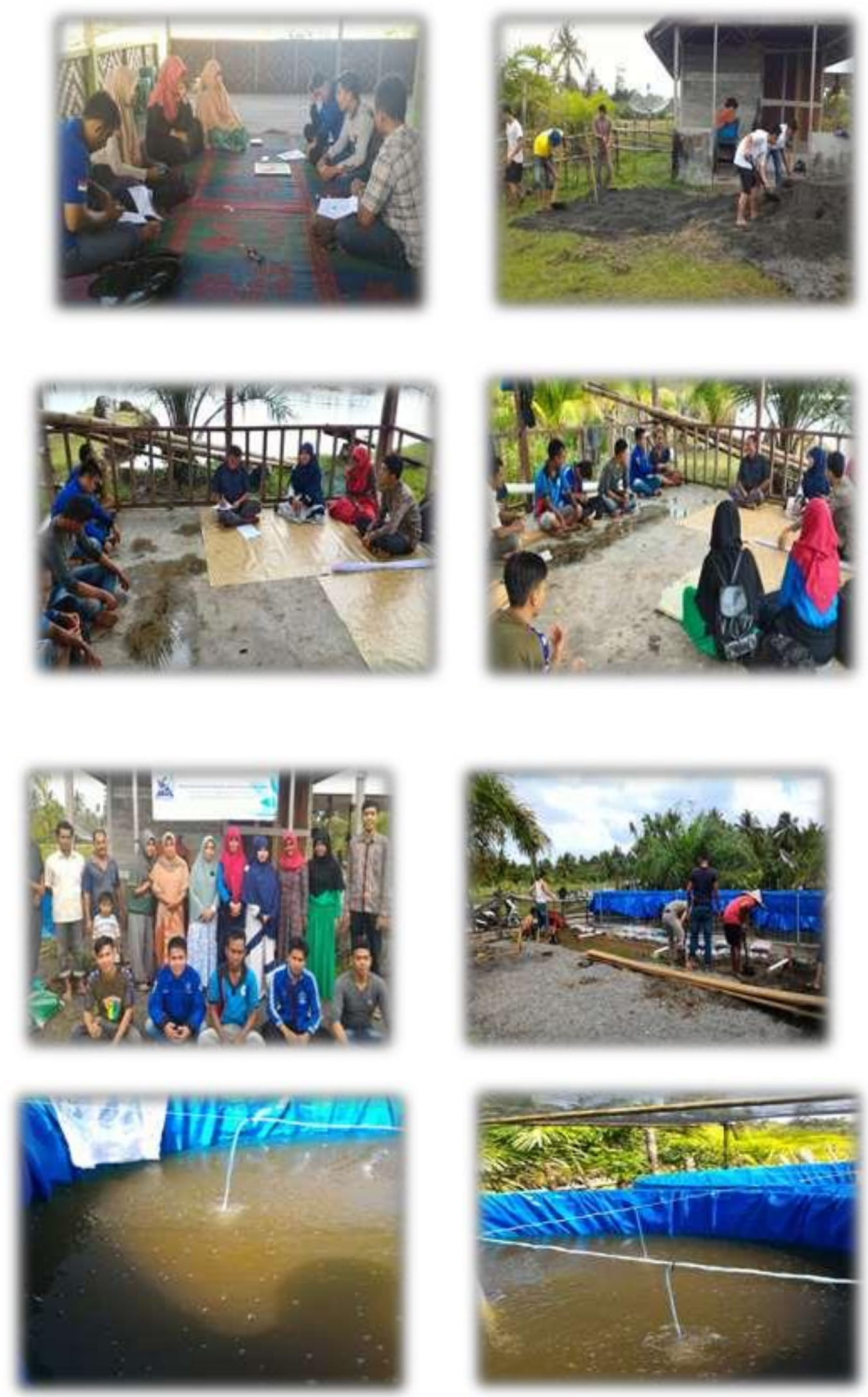

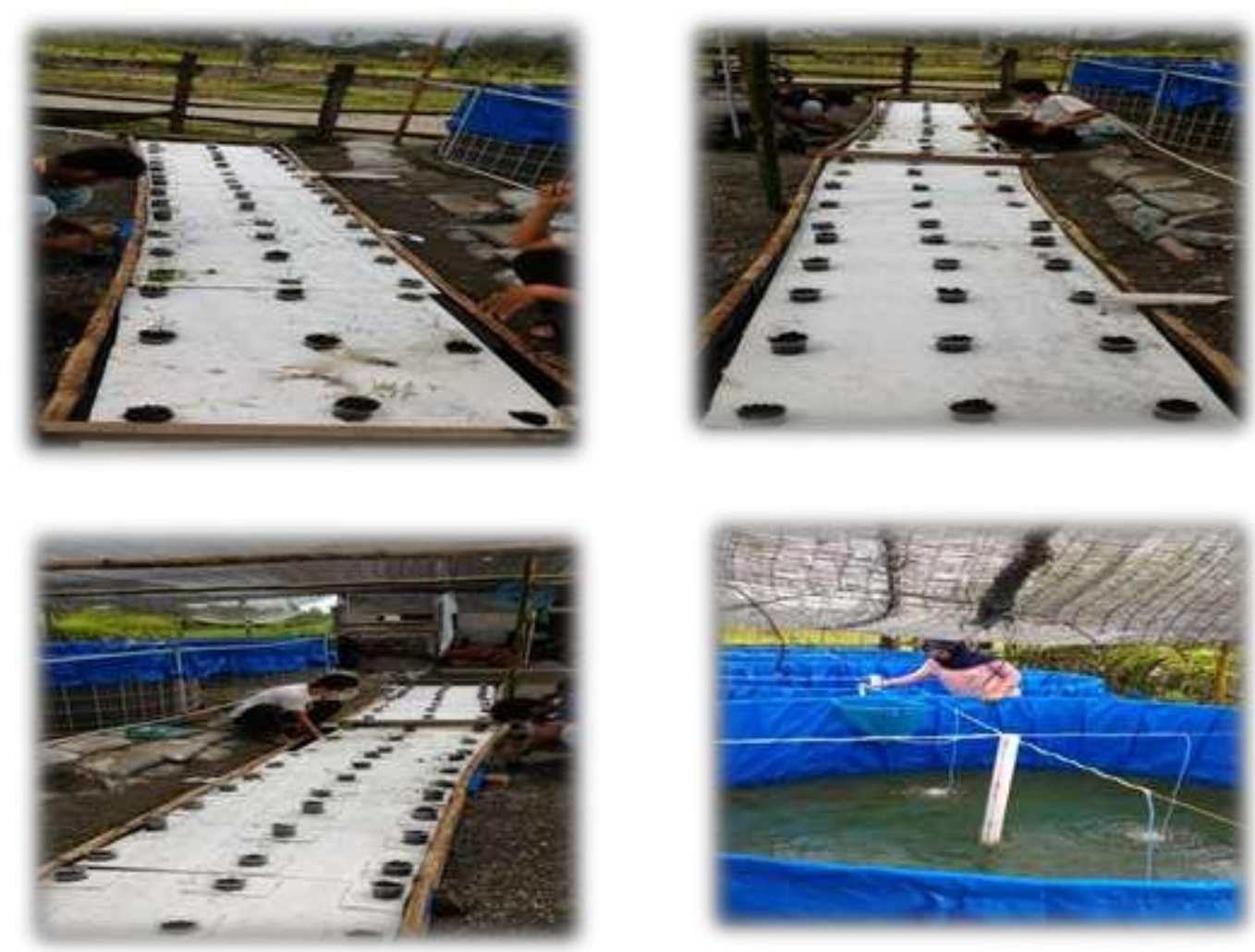